\title{
MICRO-SIZED PARTICLE PRODUCTION OF MOMORDICA SP EXTRACT USING SPRAY DRYER
}

\author{
MAIZIRWAN Mel, EMirul AdZHAR YAHYA \\ AND MOHD. RUSHDI ABU BAKAR \\ Bioprocess and Molecular Engineering Research Unit, Kulliyah of Engineering, \\ International Islamic University Malaysia. P.O. Box 10, 50728 Kuala Lumpur \\ Malaysia.
}

maizirwan@iium.edu.my

\begin{abstract}
Spray drying is the most widely used industrial process involving particle formation and drying. It is highly suited for the continuous production of dry solids in either powder, granulate or agglomerate form from liquid feed-stocks as solutions, emulsions and pump able suspensions. Therefore, spray drying is an ideal process where the end-product must comply with precise quality standards regarding particle size distribution, residual moisture content, bulk density, and particle shape. In this study, Momordica $s p$ extract product has been successfully spray dried into micro scale of powder particle and will be used as plant-based insulin. The process optimized using Taguchi method with four factors and three levels has given a good quality of the product. The average of particle size was obtained at about 11 microns.
\end{abstract}

ABSTRAK: Kering sembur digunakan secara meluas dalam proses industri yang melibatkan pembentukan zarah dan pengeringan. Ia amat sesuai dalam penghasilan pepejal kering secara beterusan dalam bentuk serbuk, butiran atau gumpalan daripada simpanan suapan bendalir sebagai larutan, emulsi dan ampaian boleh dipam. Maka, kering sembur adalah proses yang ideal apabila hasil akhir harus mematuhi piawaian kualiti yang tepat berkaitan dengan pengagihan saiz zarah, kandungan kelengsaan sisa, ketumpatan pukal dan bentuk zarah. Dalam kajian ini, produk ekstrak Momordica $s p$ (dikenali juga sebagai peria katak) telah berjaya dikering sembur menjadi serbuk zarah berskala mikro dan akan digunakan sebagai insulin berasaskan tumbuhan. Proses ini dioptimumkan dengan pengunaan kaedah Taguchi empat faktor dan tiga peringkat, agar memberikan hasil produk yang berkualiti. Kadar purata saiz zarah yang terhasil adalah lebih kurang 11 mikron.

KEY WORDS: micro-sized; particle; Momordica sp; spray dryer

\section{INTRODUCTION}

Momordica charantia also known locally as Peria Katak is an herb that helps regulate blood sugar levels and keeps body functions operating normally. It contains gurmarin, a polypeptide considered to be similar to bovine insulin, which has been shown in experimental studies to achieve a positive sugar regulating effect by suppressing the neural response to sweet taste stimuli. Clinical studies for p-Insulin was tested in a controlled clinical trial. In juvenile diabetics, the peak hypoglycemic effect was observed after 1-8 hrs and in patients with maturity onset diabetes; maximum fall in blood sugar level was noted after 12 hours [1].

The fruits and leaves of the plant contain two alkaloids, one of them being momordicine. The plant is reported to contain a glucoside, a saponin-like substance, a 
resin with an unpleasant taste, an aromatic volatile oil and mucilage. The seeds contain an alkaloid and an anthelmintic principle in the germ; they also contain urease. The fruits, leaves and extracts of Momordica charantia possess pharmacological properties and medicinal uses. It is useful as an emetic, purgative, in bilious affections, burning soles of the feet, as an anthelmentic, in piles, leprosy, jaundice, as a vermifuge, astringent in hemorrhoids, as a stomachic, antispasmodic, antioxytocic, hypoglycemic, antipyretic, mild hypotensive, and anorectic [2].

Spray drying is the transformation of a liquid feed containing solids (dissolved and/or suspended) into a dried particular form. The solvent evaporates and a dry solid in the form of a powder is formed. The spray drying process is unique in being able to produce powders of specific particle size and moisture content. Materials that are spray dried vary from plastics to ceramic materials, detergents, food products pharmaceuticals, agrochemicals, fruit and vegetables, cocaine to bone glue [3].

The application of the spray drying encapsulation technique is to prepare "dehydrated" powders of substances which do not have any water to dehydrate. For example, instant drink mixes are spray dries of the various chemicals which make up the beverage [4].

In this experiment, the most important criteria for spray drying are to maintain constant moisture content of the powder. This is required to meet legal standards and for maintaining a uniform quality of product. Average operating conditions for spray drying of herbal extract powder will vary somewhat depending upon the dryer system used and must be adjusted to produce the desired uniform moisture can be controlled by changing the conditions. It was noted that the final moisture content is controlled by the relative humidity of the outlet air. If that value is too high, then the powder particles will absorb moisture rather than give moisture away.content. It is important to understand how the final moisture content.

\section{MATERIALS AND METHOD}

\subsection{Materials}

The extract of Momordica charantia was provided by Periwinkle Science Sdn.Bhd. Production process of the extract starts from receiving of raw materials which then followed by raw material processing, extraction process and GMP processes. From raw material handling, the received herbs was processed as soon as possible in order to avoid any damage or contamination of material.

The next step was drying the herb. Drying of herbs is important as to avoid microbial growth which then could damage the material. As for the herb under process, standard moisture content was set at below $10 \%$. Drying process was using oven dryer. For the oven drying, it was set up at $70^{\circ} \mathrm{C}$ for 4 hours.

The raw material that already dried was processed in extraction plant in 4 hours duration with temperature of $110^{\circ} \mathrm{C}$. The ratio used was $100 \mathrm{~kg}$ of raw material alongside with $1000 \mathrm{~L}$ of deionized water. The extraction plant itself, is supported by five support systems which are: electric boiler, cooling tower, compressor, deionized water, vacuum system.

The extraction plant is divided by two main sections which are the extraction chamber and the concentration chamber. Raw material was placed in the heating tank of the extraction chamber. At this stage, deionized water of quantity 10 times the raw material is 
used $(1000 \mathrm{~L}$ for $100 \mathrm{~kg}$ of raw material). At the end of the process, there were first discharge and second discharge. The discharge was the herbs extract diluted in water (liquid extract). It then pumped into storage tank (capacity: $2000 \mathrm{~L}$ ). When it reached the storage tank, it was let to cool down to room temperature.

The discharge from storage tank was pumped periodically into vacuum concentrating chamber. The periodic flow of discharge into concentrating chamber was manually controlled as the automatic controller is not efficient enough. This was to avoid risk of bubbles flowing into vacuum chamber. Such condition will jeopardize the functionality of the vacuum system and even the extraction plant. The overall concentration process consumed 5 hours of time with $55^{\circ} \mathrm{C}$ of temperature. The gross yield of concentrating process is $4.4 \%$.

\subsection{Equipment and Instruments}

The equipments and instruments used in this study are pilot spray dryer (Niro, MOBILE MINOR), moisture content analyzer, particle size analyzer and FESEM (Philip).

\subsection{Experimental Design for Process Conditions}

The experiment was designed using STATISTICA by Taguchi Method Matrix, L9 [5]. There were 9 runs that carried out in this study. The parameter for each run is shown in Table 1.

Table 1: Spray dryer setting parameters and experimental results.

\begin{tabular}{|c|c|c|c|c|c|c|}
\hline Run & $\begin{array}{c}\text { Inlet } \\
\text { Temp } \\
\left({ }^{\circ} \mathbf{C}\right)\end{array}$ & $\begin{array}{c}\text { Outlet } \\
\text { Temp } \\
\left({ }^{\circ} \mathbf{C}\right)\end{array}$ & $\begin{array}{c}\text { Atomic } \\
\text { Pressure } \\
(\text { bar })\end{array}$ & $\begin{array}{c}\text { Sample } \\
\text { Concentration }\end{array}$ & $\begin{array}{c}\text { Moisture } \\
\text { Content } \\
(\%)\end{array}$ & $\begin{array}{c}\text { Particle } \\
\text { Size } \\
(\boldsymbol{\mu m})\end{array}$ \\
\hline 1 & 120 & 70 & 3.5 & $1 \mathrm{x}$ & - & 9 \\
\hline 2 & 150 & 70 & 4.5 & $2 \mathrm{x}$ & 8.87 & 11 \\
\hline 3 & 180 & 70 & 5.5 & $3 \mathrm{x}$ & 12.49 & 9.5 \\
\hline 4 & 120 & 80 & 4.5 & $3 \mathrm{x}$ & 8.93 & 12 \\
\hline 5 & 150 & 80 & 5.5 & $1 \mathrm{x}$ & - & 10 \\
\hline 6 & 180 & 80 & 3.5 & $2 \mathrm{x}$ & 5.44 & 13 \\
\hline 7 & 120 & 90 & 5.5 & $2 \mathrm{x}$ & 8.59 & 12.5 \\
\hline 8 & 150 & 90 & 3.5 & $3 \mathrm{x}$ & 8.68 & 11 \\
\hline 9 & 180 & 90 & 4.5 & $1 \mathrm{x}$ & - & 12 \\
\hline
\end{tabular}

Prior to start up the spray dryer: Prior to the start up the following was checked: 1) Checked the centralizing of the two-fluid nozzle. For rotary atomizer, the liquid distributor and the atomizer wheel must be correctly mounted having the specified distance between them. The atomizer wheel was checked that they freely rotate, 2) Checked rotation of the feed pump, 3) Checked all connection for tightness. All gaskets were correctly mounted. No false air was sucked into the dryer system due to leakage around the duct connections, 4) The glass jars under the cyclone and drying chamber were check that fastened securely. The glass jar was clean and dry. The glass jar was preheated to prevent condensation in the jar during early stages of the drying process, 5) The silencer was checked and mounted on rotary atomizer, 6) The atomizer was then tightened. 
Starting up procedure with rotary atomizer: The starting up procedure with rotary atomizer; 1) The power was switch on by turning on the main switch located on the front of the electric control panel, 2) The damper opened after the cyclone and the fan was start 3) The inlet temperature controller was set, 4) The heater was turn on, 5) The rotary atomizer started by turning the valve on. On the pneumatic control panel front slowly go to full speed, which reached after approximately 30 seconds. A gradually decreasing squealing sound was observed during acceleration. The air pressure indicated in the pressure gauge was kept constant, 6) The feed pump started slowly, when desired outlet temperature was passed by approximately $10^{\circ} \mathrm{C}$ on the outlet indicator, by pushing the button number 7 and pass distilled water to the atomizer until the required outlet temperature is stable, 7) Switch from distilled water to product, 8) The outlet temperature adjusted by changing the amount of feed led through the feed pump, 9) The atomizer speed was keep constant in order to obtain a homogenous atomization. Decreasing speed results in increasing particle size and vice versa. Too large particles can result in wet chamber deposits.

Plant in operation: The drying operation was controlled by maintenance of the required outlet air temperature at a constant inlet temperature. For a given feed liquid of constant physical properties the outlet temperature was related directly to moisture content; decrease the temperature increase the moisture content. The outlet temperature was manually controlled by regulation of the pump speed. The outlet air temperatures do not change, once the feed rates has been adjusted. It was observed that alterations of viscosity and solids content of the product influenced the outlet air temperature. When the feed rate is too large it was likely that the powder already in the chamber absorbed moisture and stick to the chamber wall. The powder was collected in the glass jar mounted under the cyclone and under the chamber cone. It was important that the glass jar under the cyclone is exchanged before it becomes completely full.

Shutting down: The shutting down procedure are; 1) Exchange the powder glass jar, 2) Change the feed to distilled water, 3) Keep the constant outlet temperature. Decreasing temperature will result in absorption of excess water in the powder still being present in the chamber, 4) Run with distilled water 5 to 10 minutes, 5) Switch of the process gas heater, 6) Switch off the pump, 7) After approximately 3 minutes switch off the atomizer device, 8) Keep the fan running for at least 5 minutes to cool the plant down, 9) When outlet temperature is below $50^{\circ} \mathrm{C}$ the chamber roof can be opened pressing button 12 and 18 at the same time. Be sure that no people are standing in reach of the chamber while lifting or lowering the roof, 10) Remaining powder in the chamber can be swept down while the fan is still running to collect the particles in the cyclone, 11) Switch off the fan, 12) Turn off main switch.

Emergency Shut Down: This are the step that should be taken for emergency shut down; 1) Turn of main switch, 2) If separate power supply to feed pump, turn it off, 3) Stop atomizer, 4) Do not open the chamber roof until the plant has cooled down, surfaces may be hot.

Cleaning: The atomizer wheel and the liquid distributor removed from the atomizer and cleaned immediately after operation. The atomizer was kept in its box when not in use.

Dry cleaning: The camber roof lifted and turned vertically upwards. When the roof was in upright position, the locking pin was inserted. This is safety precaution. The powder then brush down from the chamber walls and roof leaving the fan running. The powder then collected in the glass jars. 
Wet cleaning: The fan was stopped and the electrical power supply switched off. Demounted the glass jars. The interior of the chamber then wash down.

Precaution: The precaution step taken by removing the atomizer device before lifting the chamber roof. It was avoided spraying water directly on the instrument panel or the light fixture.

\subsection{Sample Analysis}

Total yield: The total quantities of the end product (the powder) were calculated by taking the final weight of the final product that is in powder form. This analysis carried out to find the best condition to produced maximum quantity of final product.

Moister content: The moister content of the powder were tested by using Moister Content Analyzer. The systems were based on the percentage difference of the wet weight and the dry weight. Moisture content (wet basis) was computed as $\mathbf{M}_{\mathrm{wb}}=\mathrm{mb}-\mathrm{ma} / \mathrm{mb}$, where $\mathrm{mb}=$ mass of powder before infrared treatment, $\mathrm{ma}=$ mass of powder after infrared treatment. For stability, this should be $<10 \%$ for herbal product.

Particle size: The extract powder collected from the spray dryer at the end and analyzed with particle size analyzer and FESEM. This analysis was carried out to see the distribution of the particle size produced from the different set of parameters.

\section{RESULTS AND DISCUSSION}

Referring to the experimental results in Table 1, we can see that from all runs (1-9) that have been conducted, the quality of the final product varies for all the run. This shows that the changes in the control variable do affect the production of the final product either moisture content or size of product particle. Run 1, 5 and 9 considered to be out of spec as the final quantity are too low that is below 1 gram thus no moisture content test has been conducted.

\subsection{Moisture content}

Run 1, 5 and 9 were omitted from moisture content test. From the result, the inlet, outlet temperature and the atomic pressure significantly affect the moisture content of the final product. This is due to the concept that the initial contact between spray droplets and drying air controls evaporation rates and product temperatures in the dryer [4]. It was measured by weighing a quantity of dried powder, then subjecting it to infrared radiation to drive of all residual moisture and, watching its weight until it levels off. Moisture content (wet basis) was computed as $\mathrm{M}_{\mathrm{wb}}=\mathrm{mb}-\mathrm{ma} / \mathrm{mb}$, where $\mathrm{mb}=$ mass of powder before infrared treatment, ma $=$ mass of powder after infrared treatment.

In the experiment, it was found that for outlet temperature, the condition was dependent upon liquid feed intake. If the feed intake is increased, the outlet temperature will be dropped. If the intake is reduced, the outlet temperature will increase and approach the inlet temperature. The outlet temperature will also be affected by the air flow rate. For a constant inlet temperature and constant feed intake, an increase in the air flow will raise the outlet temperature [6]. Once in feed temperature has been set, feed rate is a function of desired moisture. If the feed rate is too high or the outlet temperature is too low, product moisture and bulk density will usually be higher. Increased feed (fluid product) temperature can also increase the powder's bulk density by forming smaller spherical droplets or by de-aerating the fluid. Dilution of the feed can have an identical effect. 
The problem of humidity or the moisture content was controlled by dropping the product from the single-stage dryer into a fluid bed dryer/cooler. Most of the drying occurs within the spray-dryer, but the final moisture can be higher than in the single-stage dryer final drying occurs over more time and at a lower temperature in the fluid bed. Energy costs can easily be decreased $15 \%$ to $20 \%$, and product quality is more constant. An added benefit, due to the fluid bed, is the ability to re-wet and agglomerate if this type of product is needed. This technique had been applied to several dairy products, including skim-milk powder (low, medium and high heat); instantized skim-milk powder; whey powder; permeate; whey/fat blends; cheese powder; ice-cream powder; and whole-milk powder. Air-to-air or air-to-liquid heat recuperators also could be used to recover energy from dryer and fluid-bed exit air to further reduce energy costs [6].

\subsection{The Particle Size Distribution}

This experiment manages to study the particle size distribution of the powdered Momordica charantia. It was found that the type of atomizer determines the size and sizes distribution of the drop and their trajectory and speed. In this experiment, rotary atomizer were used and the particles produced were relatively small $(9-13 \mu \mathrm{m})$ as shown in Fig. 1. This atomizer can handle a wide variety of stream with different physical properties, and its large flow ports result in a negligible tendency to clog [7]. Atomization is generally accomplished by one of three basic devices: a single-fluid (or pressure) nozzle, a two-fluid nozzle, or a rotary atomizer (also known as a spinning disc or a wheel). The single-fluid nozzle allows more versatility in terms of positioning with the spray chamber, so the spray angle and spray direction can be varied.

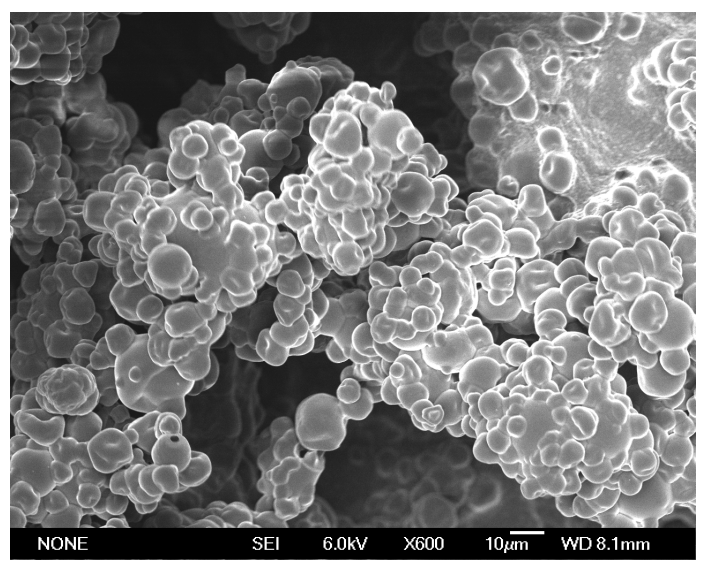

Fig. 1: SEM-photograph of spray dried and agglomerated powder.

Since it was known from this experiment that particle size is partially depend on the feed rate, nozzles have more limitations in terms of product characteristics and operating rates. Once the nozzle is in place, rate can only be varied by pressure; changing the orifice requires removing the nozzle. In high-volume operations, several nozzles are located within the chamber and positioned so constant evaporation conditions are maintained around each nozzle. For more viscous or abrasive feeds, two-fluid nozzles are utilized, with air being the second medium to move the feed and effectively atomize it. Air can be mixed internally within the nozzle or externally to the nozzle. In situations in which small particle sizes might not be possible with a single-fluid nozzle, the two-fluid nozzle can 
provide the necessary additional atomization however; this produces a much wider particle size range.

During the experiment, it was also found that the physical properties of a powder are also very depending upon the total solids concentration of the liquid which was being dried. If the droplets are maintained at a constant size, then, the amount of solids will affect both the size and the density of the dry particles. The structure of a spray-dried particle is a hollow sphere, with the solids being a shell which surrounds a central vacuole. As the total solids of the feed increases, the shell becomes thicker and, as a consequence, the particle does not shrink as much during drying. Similarly, as the air-filled vacuole decreases in size, the particle density increases. The increase in particle density has a pronounced influence on the efficiency of powder separation/collection by the cyclones, because these operate on the principle of a difference in the buoyant density difference between air and particles [8].. It is well-known in the spray-drying industry that drying a liquid of low solids content is the cause of very fine particles which are difficult to collect.

It was identified that spray-drying was an energy-intensive process. For standard single-stage drying, the best way to control energy usage is raising the inlet temperature as high as possible, keeping outlet temperature as low as possible, taking full advantage of the energy introduced. The downside of this is potential degradation or discoloration of the product, and potential final moisture problems [6].

\subsection{Effect of Parameters on Particle Size Forming}

Figure 2 shows the means plot analysis on particle size of Momordica dried product. This indicates the inversely proportional for all factors. The main factor that confers the smaller particle size was the outlet temperature which was the low level of outlet temperature. The second factor that may also influence the particle size of Momordica dried product was the sample concentration where less concentration gives the smaller particle. Then, smaller particle was also influenced by higher pressure and medium level of inlet temperature. The incline line at atomization pressure means higher atomization pressure is better. The decline line at feed concentration means lower feed concentration is better.

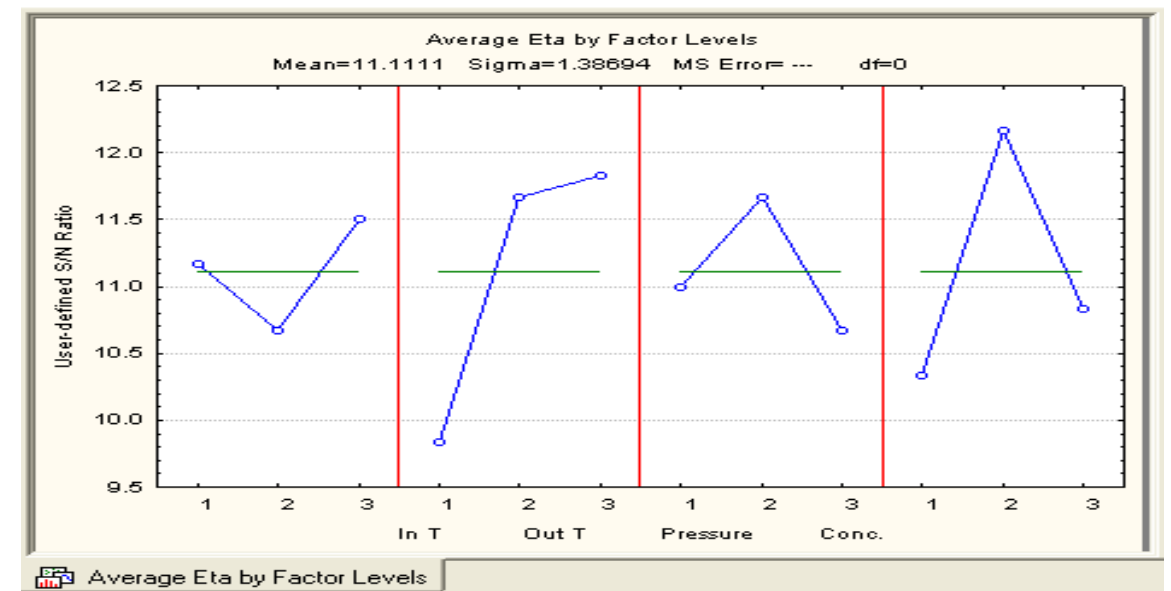

Fig. 2: Means Plot of factors on product particle size. 
Table 2: The correlation analysis between Inlet Temperature and Outlet Temperature.

\begin{tabular}{|c|c|c|c|c|c|}
\hline \multirow[b]{2}{*}{ Effect } & \multicolumn{5}{|c|}{$\begin{array}{l}\text { Analysis of Variance (amirul-taguchi) } \\
\text { Mean = } 11.1111 \text { Sigma }=1.38694 \\
* \text { - effect pooled into error term }\end{array}$} \\
\hline & SS & $d f$ & MS & $\mathrm{F}$ & $p$ \\
\hline${ }^{*} \operatorname{In} T$ & 1.055556 & 2 & & & \\
\hline${ }^{*}$ Out T & 7.3888889 & 2 & & & \\
\hline *Pressure & 1.555556 & 2 & & & \\
\hline${ }^{*}$ Conc. & 5.388889 & 2 & & & \\
\hline 1 by 2 & 6.944445 & 4 & 1.736111 & 0.822368 & 0.572873 \\
\hline Residual & 8.444445 & 4 & 2.111111 & & \\
\hline
\end{tabular}

Table 3: The correlation analysis between Inlet Temperature and pressure.

\begin{tabular}{|c|c|c|c|c|c|}
\hline \multirow[b]{2}{*}{ Effect } & \multicolumn{5}{|c|}{$\begin{array}{l}\text { Analysis of Variance (amirul-taguchi) } \\
\text { Mean }=11.1111 \text { Sigma }=1.38694 \\
* \text { - effect pooled into error term }\end{array}$} \\
\hline & SS & $d f$ & MS & $\mathrm{F}$ & $p$ \\
\hline${ }^{*} \operatorname{In} T$ & 1.05556 & 2 & & & \\
\hline${ }^{*}$ Out $T$ & 7.38889 & 2 & & & \\
\hline *Pressure & 1.55556 & 2 & & & \\
\hline *Conc. & 5.38889 & 2 & & & \\
\hline 1 by 3 & 12.77778 & 4 & 3. 194444 & 4.893617 & 0.076599 \\
\hline Residual & 2.61111 & 4 & 0.652778 & & \\
\hline
\end{tabular}

Table 4: The correlation analysis between Inlet Temperature and Sample Concentration.

\begin{tabular}{|c|c|c|c|c|c|}
\hline \multirow[b]{2}{*}{ Effect } & \multicolumn{5}{|c|}{$\begin{array}{l}\text { Analysis of Variance (amirul-taguchi) } \\
\text { Mean }=11.1111 \text { Sigma }=1.38694 \\
{ }^{*} \text { - effect pooled into error term }\end{array}$} \\
\hline & SS & $\mathrm{df}$ & MS & $\mathrm{F}$ & $p$ \\
\hline${ }^{*} \ln T$ & 1.055556 & 2 & & & \\
\hline${ }^{*}$ Out $T$ & 7.388889 & 2 & & & \\
\hline *Pressure & 1.555556 & 2 & & & \\
\hline${ }^{*}$ Conc. & 5.388889 & 2 & & & \\
\hline 1 by 4 & 8.944445 & 4 & 2.236111 & 1.387931 & 0.379231 \\
\hline Residual & 6.444445 & 4 & "1.611111 & & \\
\hline
\end{tabular}

Table. 5: The correlation analysis between Outlet Temperature and Sample Concentration.

\begin{tabular}{|c|c|c|c|c|c|}
\hline \multirow[b]{2}{*}{ Effect } & \multicolumn{5}{|c|}{$\begin{array}{l}\text { Analysis of Variance (amirul-taguchi) } \\
\text { Mean }=11.1111 \text { Sigma }=1.38694 \\
{ }^{*} \text { - effect pooled into error term }\end{array}$} \\
\hline & SS & $\mathrm{df}$ & MS & $\mathrm{F}$ & $p$ \\
\hline${ }^{*} \ln T$ & 1.05556 & 2 & & & \\
\hline${ }^{*}$ Out T & 7.38889 & 2 & & & \\
\hline${ }^{*}$ Pressure & 1.55556 & 2 & & & \\
\hline${ }^{*}$ Conc. & 5.38889 & 2 & & & \\
\hline 2 by 4 & 2.61111 & 4 & 0.652778 & 0.204348 & 0.923401 \\
\hline Residual & 12.77778 & 4 & 3.194444 & & \\
\hline
\end{tabular}


Table 6: The correlation analysis between Pressure and Sample Concentration.

\begin{tabular}{|c|c|c|c|c|c|}
\hline \multirow[b]{2}{*}{ Effect } & \multicolumn{5}{|c|}{$\begin{array}{l}\text { Analysis of Variance (amirul-taguchi) } \\
\text { Mean }=11.1111 \text { Sigma }=1.38694 \\
* \text { - effect pooled into error term }\end{array}$} \\
\hline & SS & $d f$ & MS & $\mathrm{F}$ & $p$ \\
\hline${ }^{*} \ln T$ & 1.055556 & 2 & & & \\
\hline${ }^{*}$ OutT & 7.388889 & 2 & & & \\
\hline${ }^{*}$ Pressure & 1.555556 & 2 & & & \\
\hline${ }^{*}$ Conc. & 5.388889 & 2 & & & \\
\hline 3 by 4 & 8.444445 & 4 & 2.111111 & 1.216000 & 0.427127 \\
\hline Residual & 6.944445 & 4 & 1.736111 & & \\
\hline
\end{tabular}

\subsection{The Variables (Factors) Correlations}

Referring to Table 2-6, the correlation between the controlled parameter and the measured parameter, the combination factors inlet temperature and pressure gives the significant affect on the final product as shown at $\mathrm{p}$ value of 0.076599 . Changes in the temperature and pressure level produced a very significant difference to the quality of the final product. By using temperature $150^{\circ} \mathrm{C}$ and pressure of 5.5 bars, it would yield a better product in term of quantity and quality. As explained by Blei [9] the product moisture and particle size is always relevance with temperature.

\section{CONCLUSION}

This study has identified the best condition to improve and optimize the spray drying condition leading towards a high quality of powdered Momordica $s p$ and producing the standard optimum moisture content $(<10 \%)$. By controlling the parameters especially temperature and pressures lead to better quality of the product. This experiment was successful to identify the best condition for producing a best end product base on the quality. From the result obtained, the average particle size is $11.1 \mu \mathrm{m}$ at optimum condition with inlet temperature of $150^{\circ} \mathrm{C}$, outlet temperature of $70^{\circ} \mathrm{C}$, atomic pressure of 4.5 bars and at least sample concentration $(1 \mathrm{x})$ yield the best result both on the moisture content and the particle yield.

\section{ACKNOWLEDGEMENT}

We would like to acknowledge the Kulliyyah of Engineering especially the Department of Biotechnology Engineering, International Islamic University Malaysia for the support of this project.

\section{REFERENCES}

[1] B Draznin., D LeRoith, Molecular Biology of Diabetes: Autoimmunity and Genetics; Insulin Synthesis and Secretion. Humana Press, New Jersey. 1994.

[2] OL Johnson, W Jaworowicz, JL Cleland, L Bailey, M Charnis, E Duenas, C Wu, D Shepard, S Magil, T Last, AJS Jones, SD Putney. Herbal: The pharmacological properties of Momordica charantia. Pharm. Res.; 14:730-735. 1997. 
[3] Toba, T., Abe S., Arihara K. and Adachi S. Spray Drying Technology and the Concepts. Agric. Biol. Chem., 50, 2673-2674. 1986.

[4] P. Menn, G. Schulte, K. Bauckhage, Experimental Investigation of High Pressure Spray Drying Nozzle Performance at Industrial Operating Conditions', Proc. $9^{\text {th }}$ International Conference on Liquid Atomization and Spray Systems, July 13-17, Sorrento, Italy,2001.

[5] V N Nair, Taguchi's parameter design: a panel discussion, Technometrics. Vol. 34, pp127-161. 1992

[6] J.G.P. Verhey, Vacuole formation in spray powder particles. 1. Air incorporation and bubble expansion. Neth. Milk Dairy J. 26: 187-202. 3. 1972 and 1973.

[7] I Filkova, and A.S Mujumdar, Industrial Spray Drying System, in Handbook of Industrial Drying, Mujumdar, A.S., Ed., Marcel Dekker, New York, Vol. 1, Part II chapter 9, 263-300, 1995.

[8] T. J. Buma, and S. Henstra, Particle structure of spray-dried caseinate and spraydried lactose as observed by a scanning electron microscope. Neth. Milk Dairy J. 25: 278-281. 1971

[9] S. Blei, M. Sommerfeld, Lagrangian Modeling of Agglomeration During Spray Drying Processes', Proc. $9^{\text {th }}$ International Conference on Liquid Atomization and Spray Systems, July 13-17, Sorrento, Italy. 1999. 